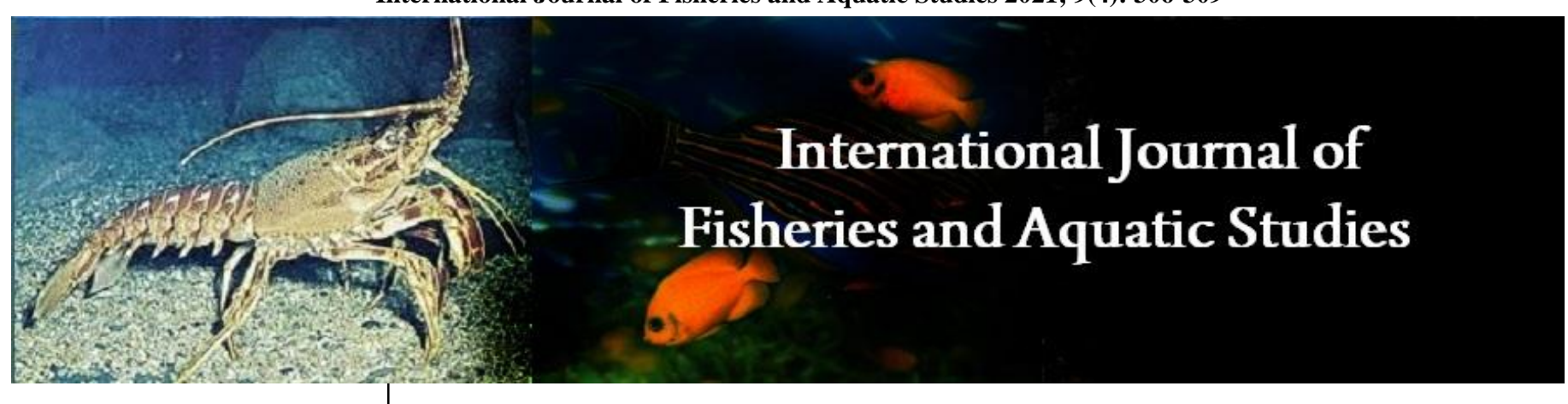

E-ISSN: 2347-5129

P-ISSN: 2394-0506

(ICV-Poland) Impact Value: 5.62

(GIF) Impact Factor: 0.549

IJFAS 2021; 9(4): 306-309

(C) 2021 IJFAS

www.fisheriesjournal.com

Received: 10-05-2021

Accepted: 12-06-2021

Mrinmoy Choudhury

ICAR-Krishi Vigyan Kendra

Hailakandi, Assam, India

Sayon Paul

ICAR-Krishi Vigyan Kendra

Hailakandi, Assam, India

Dr. Bijoy Chhetri

ICAR-Krishi Vigyan Kendra

Hailakandi, Assam, India
Corresponding Author: Mrinmoy Choudhury ICAR-Krishi Vigyan Kendra Hailakandi, Assam, India

\section{Study on fish catching devices used by the fishing community of Dewaddhar village of Sonebeel, Assam, India}

\section{Mrinmoy Choudhury, Sayon Paul and Dr. Bijoy Chhetri}

DOI: $\underline{\text { https://doi.org/10.22271/fish.2021.v9.i4d.2548 }}$

\begin{abstract}
The present study was intended to document the various fishing gears used by the fishermen community of Dewaddhar Village of Sonebeel. A field survey was conducted to catalogue the different traditional fishing gears of the area along with the efficacy of those gears, which revealed around 8 different types of fishing gears and around 40 species of ichthyofauna belonging to 20 families.
\end{abstract}

Keywords: Dewaddhar village, Sonebeel, fishing gears, ichthyofaunal diversity, fishermen community

\section{Introduction}

The North-Eastern region of India is harbored by extensive lentic and lotic water bodies of which prominent wetlands like Sonebeel is the home to a wide diversity of ichthyofauna.

Sonebeel has an area of around 3458.12 ha and is considered as the largest seasonal wetland of Assam and the second largest in Asia. Sonebeel has geographic coordinates between $92^{\circ} 24^{\prime} 50^{\prime \prime}$ to $92^{\circ} 28^{\prime} 25^{\prime \prime} \mathrm{E}$ and $24^{\circ} 36^{\prime} 40^{\prime \prime}$ to $24^{\circ} 44^{\prime} 30^{\prime \prime} \mathrm{N}$ and falls in Karimganj district of Assam. The beel is fed with water by the major inflow of the Singla River alongside 12 minor inlets. The major outflow of the beel is River Kachua which drains the water from Sonebeel to the mighty Kushiara River.

Sonebeel shows the characteristics of seasonal wetland and it reaches its full storage level during monsoon months and the fishermen community (consisting of mainly Kaibarta and Patni) engage themselves in extensive fishing in the beel area. The beel dries up during winter months leaving a vast fertile cultivable paddy land commonly used by the locals for paddy cultivation.

Many species of commercial and non-commercial importance are abundantly found in Sonebeel. A diversity is also seen in the operation of fish-catching devices in Sonebeel which have evolved over time. The fishermen community here uses a wide array of fishing devices with varying sizes, structure and modus operandi. Many modern and traditional fishing gears are used here depending on the seasonality, water level, types of fishes to be caught etc.

The traditional fishing gears are socially significant as they speak about the traditional knowledge of the fishing communities. But improper use of fishing gears can lead to a decline in the fish production potential of this wetland and there is seen a significant decline in the fish production as per the information gathered from the locals of Sonebeel area of which overfishing or improper use of fishing gears might be a reason. Keeping all these in mind a detailed survey was conducted to study and to document the different fishing gears of this wetland.

\section{Methodology}

The present study was conducted in Dewaddhar Village (2442'07.2" $\mathrm{N}$ and $092^{\circ} 27^{\prime} 18.5^{\prime \prime} \mathrm{E}$ ) of Sone beel area during the month of February 2021. All the relevant data of the fishing gears were collected by field survey and personal interview with the fishermen.. The description of the gears and their modus operandi and other relevant information provided by the fishermen were recorded in the relevant section of the questionnaire. Information on availability of ichthyo faunal diversity was recorded. The photographs of different fishing crafts and gears were also documented. 


\section{Result}

The survey conducted in Dewaddhar Village revealed that the fishermen community of this area mainly use eight different types of fishing gears comprising of nets, hooks and bamboo traps. These gears are mostly indigenous with different size, shape, method of operation and efficacy.

Details of these fishing gears are briefly tabulated below:

Table 1: Analysis of different fishing gears operated in Dewaddhar Village of Sonebeel

\begin{tabular}{|c|c|c|c|c|c|c|c|c|c|}
\hline $\begin{array}{l}\text { Sl. } \\
\text { No. }\end{array}$ & $\begin{array}{c}\text { Gear name } \\
\text { (local name) }\end{array}$ & Gear type & $\begin{array}{c}\text { Main fishes } \\
\text { caught }\end{array}$ & $\begin{array}{c}\text { Total wt. of } \\
\text { fish caught } \\
\text { (kg) }\end{array}$ & $\begin{array}{c}\text { No. of persons } \\
\text { operating the } \\
\text { gear }\end{array}$ & $\begin{array}{l}\text { Time period of } \\
\text { gear operation }\end{array}$ & $\begin{array}{c}\text { Cost of gear } \\
\text { fabrication (Rs.) }\end{array}$ & $\begin{array}{c}\text { Total income } \\
\text { from the gear } \\
(\text { Rs. })\end{array}$ & CPGH \\
\hline 1 & Maha Jal & $\begin{array}{c}\text { Encircling } \\
\text { gear }\end{array}$ & $\begin{array}{l}\text { All kind of } \\
\text { fishes }\end{array}$ & $\approx 250$ & 16 nos. & $\begin{array}{l}\text { At night/day } \\
\text { time ( } 8 \text { hrs })\end{array}$ & $\approx 2.5$ - 3 lacs & $\begin{array}{l}\approx 8000 \text { (per } \\
\text { catch day) }\end{array}$ & 1.953125 \\
\hline 2 & Ghuran Jal & $\begin{array}{c}\text { Encircling } \\
\text { gear }\end{array}$ & $\begin{array}{l}\text { All kind of } \\
\text { fishes }\end{array}$ & 8 & 3 nos. & Day/Night (1 hr) & 40000 & $\begin{array}{c}1200 \text { (per catch } \\
\text { day) }\end{array}$ & 2.666666 \\
\hline 3 & $\begin{array}{c}\text { Jhaki Jal/Ural } \\
\text { Jal/ Reg Jal }\end{array}$ & Cast net & $\begin{array}{l}\text { Small sized } \\
\text { fishes }\end{array}$ & 5 & 2 nos. & $\begin{array}{c}\text { Day time }(30 \\
\text { min }-1 \mathrm{hr})\end{array}$ & $\approx 3000$ & $\begin{array}{c}600 \text { (per catch } \\
\text { day) }\end{array}$ & 2.5 \\
\hline 4 & Polo & $\begin{array}{c}\text { Bamboo } \\
\text { Trap }\end{array}$ & $\begin{array}{c}\text { Medium sized } \\
\text { fishes }\end{array}$ & $3-4$ & 1 no. & $\begin{array}{c}\text { Day time ( } 2-3 \\
\text { hrs) }\end{array}$ & 1000 & $\begin{array}{c}500-800 \text { ( per } \\
\text { catch day) }\end{array}$ & 1.33 \\
\hline 5 & Kuchrung Jal & Purse net & $\begin{array}{l}\text { Small sized } \\
\text { fishes }\end{array}$ & $\approx 2.5-3$ & 2 nos. & $\begin{array}{c}\text { Day/Night }(2-3 \\
\text { hrs })\end{array}$ & $1500-1600$ & $\begin{array}{c}500-600 \text { (per } \\
\text { catch day) }\end{array}$ & 0.65 \\
\hline 6 & Fash Jal & Gill net & $\begin{array}{c}\text { Small to } \\
\text { medium sized } \\
\text { fishes }\end{array}$ & $2-5$ & 6-8 nos. & $\begin{array}{c}\text { Day/Night (3-10 } \\
\text { hrs) }\end{array}$ & $5000-20000$ & $\begin{array}{c}\approx 500-2500 \text { (per } \\
\text { catch day) }\end{array}$ & 0.1111 \\
\hline 7 & Dori & $\begin{array}{l}\text { Bamboo } \\
\text { Trap }\end{array}$ & $\begin{array}{l}\text { Small sized } \\
\text { fishes }\end{array}$ & $1.5-2 \mathrm{~kg}$ & 1 no. & Night (12 hrs) & $\begin{array}{c}\text { 500-600 (per } \\
\text { trap) }\end{array}$ & $\begin{array}{c}500-700 \text { (per } \\
\text { catch day) }\end{array}$ & 0.166 \\
\hline 8 & $\begin{array}{c}\text { Hajari Borshi, } \\
6 \text { No. }\end{array}$ & $\begin{array}{c}\text { Hook and } \\
\text { line }\end{array}$ & \begin{tabular}{|c|} 
Small to \\
medium sized \\
fishes
\end{tabular} & $2-3$ & 1 no. & Night (6 hrs) & 2000 & $\begin{array}{c}300-400 \text { (per } \\
\text { catch day) }\end{array}$ & 0.5 \\
\hline
\end{tabular}

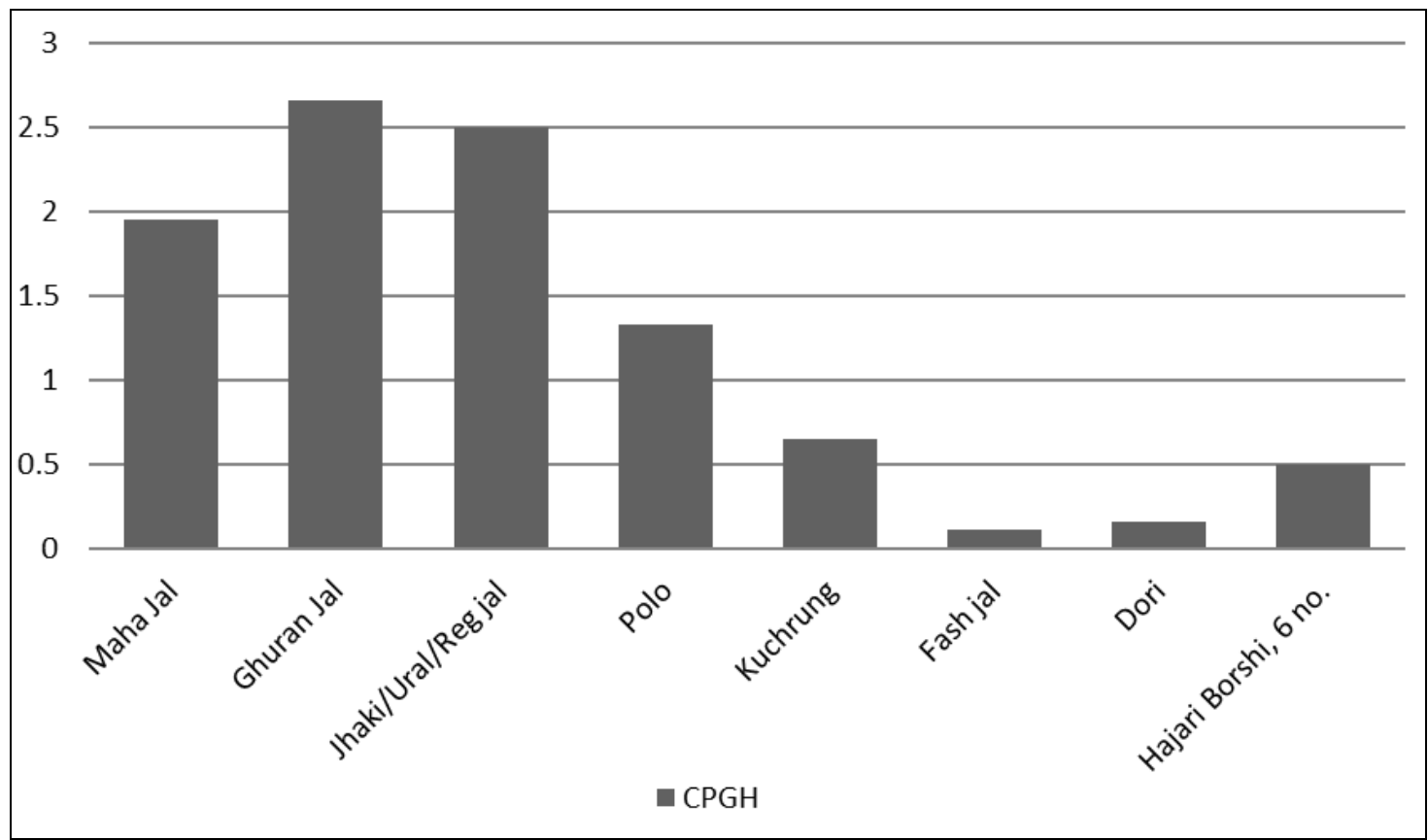

CPGH of the different fishing gears

Table 2: Status of ichthyofaunal diversity of Sonebeel (recorded from the conversation with the locals)

\begin{tabular}{|c|c|c|c|c|}
\hline Sl. No. & Scientific name & Vernacular name & Family & Availability Status \\
\hline 1 & Ailia coila & Kajuli & Ailiidae & $* * *$ \\
\hline 2 & Anabas testudineus & Koi & Anabantidae & $* * *$ \\
\hline 3 & Mystus cavasius & Tengra & Bagridae & $* * *$ \\
\hline 4 & Mystus tengara & Tengra & Bagridae & $* * *$ \\
\hline 5 & Rita rita & Ritha & Bagridae & $* *$ \\
\hline 6 & Xenentodon cancilla & Kaikka & Belonidae & $* *$ \\
\hline 7 & Botia Dario & Rani & Botiidae & $* * *$ \\
\hline 8 & Channa punctata & Cheng & Channidae & $* * *$ \\
\hline 9 & Channa striata & Shole & Clupidae & $* * *$ \\
\hline 10 & Gudusia chapra & Chapila & Cyrpinidae & $* * *$ \\
\hline 11 & Labeo rohita & Rui & Cyprinidae & $* * *$ \\
\hline
\end{tabular}




\begin{tabular}{|c|c|c|c|c|}
\hline 13 & Cirrhinus mrigala & Mrigel & Cyprinidae & $* * *$ \\
\hline 14 & Labeo calbasu & Kalia Baush & Cyprinidae & $* *$ \\
\hline 15 & Cyprinus carpio & Common Carp & Cyprinidae & $* * *$ \\
\hline 16 & Hypophthalmichthys molitrix & Silver Carp & Cyprinidae & $* * *$ \\
\hline 17 & Ctenopharyngodon idella & Grass Carp & Cyprinidae & $* * *$ \\
\hline 18 & Labeo bata & Bata/ Bhangan & Cyprinidae & $* *$ \\
\hline 19 & Chela laubuca & Chelabaia & Cyprinidae & $* * *$ \\
\hline 20 & Esomus danricus & Darkina & Cyprinidae & $* *$ \\
\hline 21 & Puntius conchonius & Shor Puthi & Cyprinidae & $* * *$ \\
\hline 22 & Puntius ticto & Puthi & Cyprinidae & $* * * *$ \\
\hline 23 & Puntius sophore & Bhari puthi & Cyprinidae & $* * *$ \\
\hline 24 & Osteobrama cotio & Chela & Cyprinidae & $* *$ \\
\hline 25 & Salmophasia bacaila & Bhaiachela & Cyprinidae & $* *$ \\
\hline 26 & Amblypharyngodon mola & Moka & Danionidae & $* *$ \\
\hline 27 & Glossogobius giuris & Baligora & Gobiidae & $* * *$ \\
\hline 28 & Mastacembelus armatus & Baim & Mastacembelidae & $* * *$ \\
\hline 29 & Nandus nandus & Bheda & Nandidae & $* * *$ \\
\hline 30 & Notopterus notopterus & Kangla & Notopteridae & $* * *$ \\
\hline 31 & Chitala chitala & Chitol & Notopteridae & $* *$ \\
\hline 32 & Pisodonophis boro & Kuchia & Ophichthidae & $* *$ \\
\hline 33 & Trichogaster fasciata & Kholisha & Osphronemidae & $* * *$ \\
\hline 34 & Pangasius pangasius & Pangas & Pangasidae & $* *$ \\
\hline 35 & Silonia silondia & Vacha & Schilbeidae & $* * *$ \\
\hline 36 & Ompok pabda & Pabda & Siluridae & $* * *$ \\
\hline 37 & Wallago attu & Boal & Siluridae & $* * *$ \\
\hline 38 & Mystus aaor & Arr & Siluridae & $* * *$ \\
\hline 39 & Monopterus cuchia & Kuchia & Synbranchidae & $* *$ \\
\hline 40 & Tetraodon cutcutia & Beng & Tetradontidae & $* *$ \\
\hline & Sies Abara & \\
\hline
\end{tabular}

Note: “****” Signifies Abundant availability; “***” Signifies Moderate availability; “**” Signifies Less availability

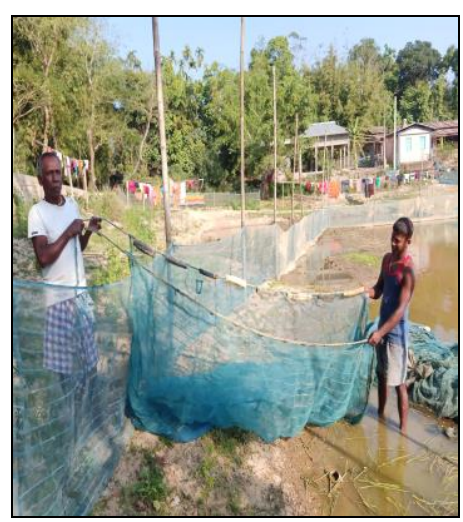

A.

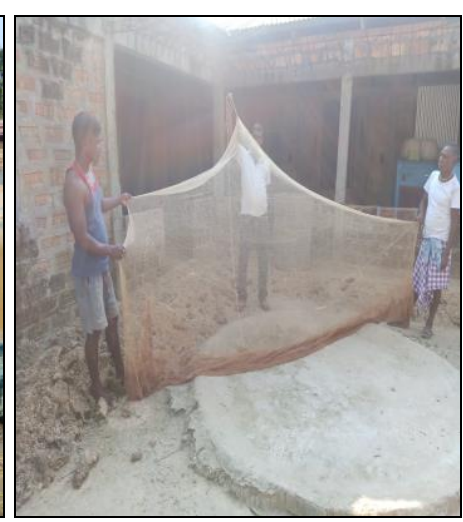

B.

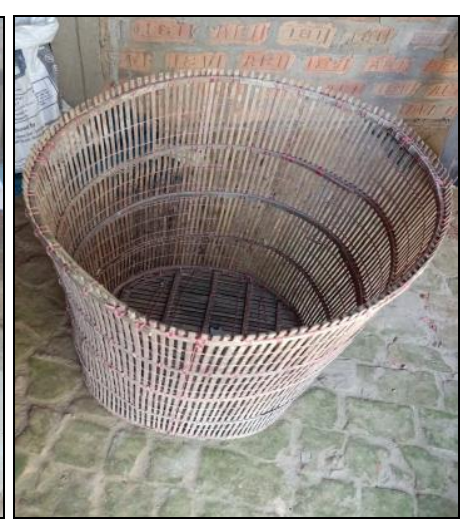

C.

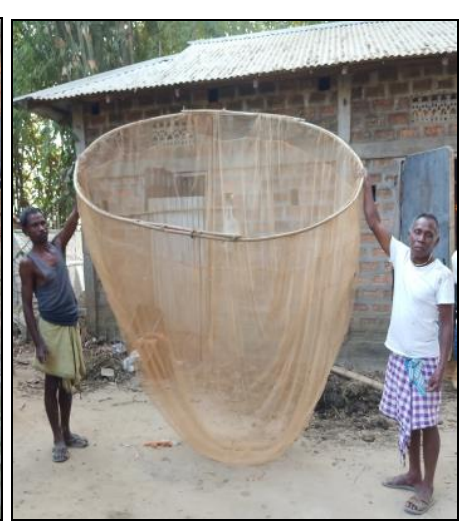

D.

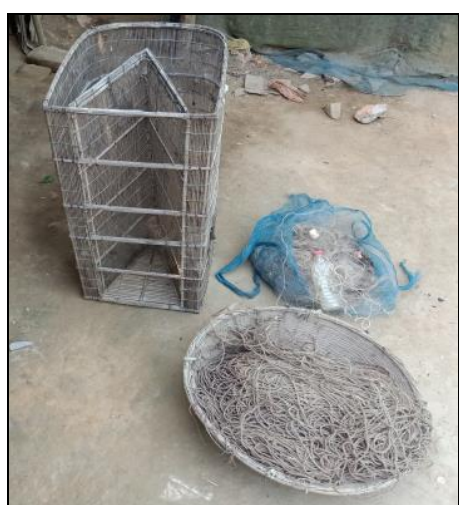

E.

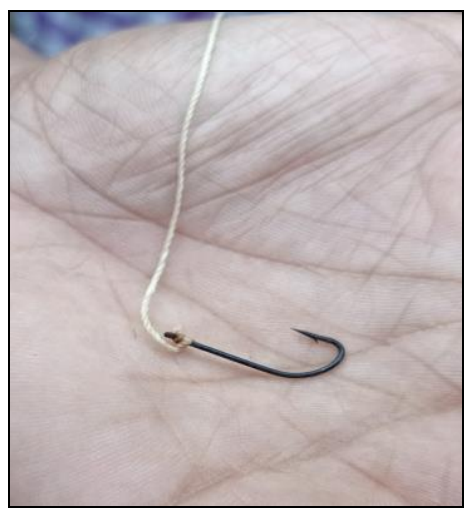

F.

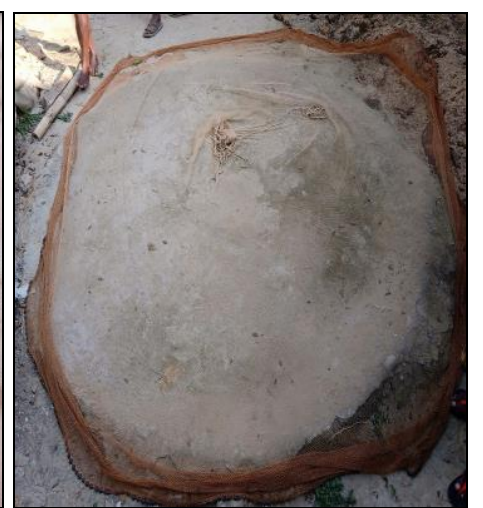

G

Fig 1: (a) Mahajal; (b) Jhakijal; (c) Polo; (d) Kuchrungjal; (e) Dori; Fashjal; Hajariborshi; (f) Hajariborshi; (g) Ghuranjal

\section{Discussion}

The field survey revealed that the fishing community of Dewaddhar Village of Sonebeel area mostly use 8 different types of fishing gears consisting of nets, bamboo traps and hook and line (Table 1), according to the availability of fish species and the physical condition of the wetland, which plays a very pivotal role on fishing operation. The discussion with the local fishermen also revealed that the majority of the locals mostly use the gill net (Fash jal) and cast net (Jhaki jal) for catching commercial fishes. 
The study also revealed that most of the gears exhibit seasonality in their operation. The Mahajal is operated mainly during the monsoon season, while the cast net (Jhaki jal) is perineal in their mode of operation. It also revealed that the different gears are operated to catch different size of fishes ranging from small, medium and large. For instance, the Mahajal is operated to catch all kind of fishes while the Hajari borshi, Dori, Polo and Kuchrung jal are used to catch medium and small fishes (Table 1).

Considering the efficacy of the gears which was determined by $\mathrm{CPGH}$ (Catch/Person/Gear/Hour) calculation, it was found that the Ghuran jal (Encircling gear) seems to be the most efficacious followed by Maha jal (Encircling gear) and Polo (Bamboo trap) (Table 1).

The present study also revealed the occurrence of 40 different species of ichthyo fauna belonging to 20 families signifying their availability status in this wetland (Table 2).

\section{Conclusion}

The study highlighted that the fishermen community of Dewaddhar village of Sonebeel area have mostly been using 8 different types of fishing gears for fishing operation. The area is inhabited by native fishermen who are dependent mostly on fishing activities to earn their livelihood besides some of them are also engaged in agricultural practices during dry season of winter when the major portion of the wetland partially dries up. The study also revealed that there is a gradual decline in the fish diversity of the wetland due to different anthropogenic as well as natural factors. Illegal (extensive fishing during breeding season, improper use of gill net etc) and overfishing might be the cause of this gradual decline which needs to be checked as it is a need of the hour to save the ichthyodiversity of this wetland on which the livelihood of the fishing community are dependent upon.

\section{Acknowledgement}

The author is thankful to the local fishermen of Dewaddhar village of Sonebeel who shared all their valuable information about the various fishing gears during the survey period. Furthermore, the author is also thankful to the officials of ICAR KVK Hailakandi for their valuable cooperation in carrying out this survey.

\section{Reference}

1. Bhattacharjee M, Mohanto B. A survey on fishing gears used for fishing in Sone beel, the largest wetland in Assam, Northeast India. International Journal of Fisheries and Aquatic Studies 2017;5(4):268-2

2. Choudhury M. Studies on Some of the Fish Catching Gears in Barak and Katakhal Drainage in Barak Valley Region of Assam. Haya: The Saudi Journal of Life Sciences 5(6):103-107.

3. Dutta R, Dutta A. Bheta fishing-A traditional community fishing practice of Nocte tribe of Tirap district, Arunachal Pradesh. Indian Journal of Traditional Knowledge 2013;12(1):162- 165.

4. Kar D. Wetlands and theirfish diversity in Assam (India). Transylv. Rev. Syst. Ecol. Res. 21.3 "The Wetlands Diversity" 2019.

5. Lalthanzara H, Lalthanpuii PB. Traditional fishing methods in rivers and streams of Mizoram, north-east India. Science vision 2009;9(4):188-194.

6. Pravin P, Meenakumari B, Baiju M, Barman J, Baruah D, Kakati B. Fish trapping devices and methods in Assam-a review. Indian journal of fishery 2011;58(2):127-135.

7. Saha B, Devi R, Kashyap D. Perceived effectiveness of indigenous traditional fishing methods including gears and traps in Nagaon district of Assam. Indian Journal of Traditional Knowledge 2015;1(1):103-111.

8. Tynsong H, Tiwari BK. Traditional knowledge associated with fish harvesting practices of War Khasi community of Meghalaya. Indian Journal of Traditional Knowledge 2008;7(4):618-623 